\title{
Fish ladders: safe fish passage or hotspot for predation?
}

\author{
Angelo Antonio Agostinho ${ }^{1}$, Carlos Sergio Agostinho ${ }^{2}$, Fernando Mayer Pelicice ${ }^{2}$ and \\ Elineide Eugênio Marques ${ }^{2}$
}

Fish ladders are a strategy for conserving biodiversity, as they can provide connectivity between fragmented habitats and reduce predation on shoals that accumulate immediately below dams. Although the impact of predation downstream of reservoirs has been investigated, especially in juvenile salmonids during their downstream movements, nothing is known about predation on Neotropical fish in the attraction and containment areas commonly found in translocation facilities. This study analysed predation in a fish passage system at the Lajeado Dam on the Tocantins River in Brazil. The abundance, distribution, and the permanence (time spent) of large predatory fish along the ladder, the injuries imposed by piranhas during passage and the presence of other vertebrate predators were investigated. From December 2002 to October 2003, sampling was conducted in four regions (downstream, along the ladder, in the forebay, and upstream of the reservoir) using gillnets, cast nets and counts or visual observations. The captured fish were tagged with thread and beads, and any mutilations were registered. Fish, birds and dolphins were the main predator groups observed, with a predominance of the first two groups. The entrance to the ladder, in the downstream region, was the area with the highest number of large predators and was the only region with relevant non-fish vertebrates. The main predatory fish species were Rhaphiodon vulpinus, Hydrolycus armatus, and Serrasalmus rhombeus. Tagged individuals were detected predating along the ladder for up to 90 days. Mutilations caused by Serrasalmus attacks were noted in $36 \%$ of species and $4 \%$ of individuals at the top of the ladder. Our results suggested that the high density of fish in the restricted ladder environment, which is associated with injuries suffered along the ladder course and the presence of multiple predator groups with different predation strategies, transformed the fish corridor into a hotspot for predation.

Passagens para peixes têm sido consideradas como estratégias para conservação da biodiversidade, visando além de assegurar os deslocamentos entre habitats fragmentados, atenuar a mortalidade por predação dos estratos populacionais que se concentram nos trechos imediatamente abaixo de barragens. Embora a mortalidade por predação no trecho a jusante de reservatórios tenha sido bem investigada, especialmente sobre os juvenis de salmonídeos em movimentos descendentes, nada se sabe acerca da predação de peixes neotropicais em áreas de atração e confinamento de peixes, eventos comuns a essas facilidades de transposição. Nesse estudo são analisados aspectos da predação em um sistema de transposição de peixes (barragem de Lajeado, rio Tocantins, Brasil), buscando avaliar a abundância, a distribuição e o tempo de permanência de grandes peixes predadores na escada, as injúrias impostas por piranhas durante a passagem e a ocorrência de outros vertebrados predadores. Para isso foram realizadas amostragens a jusante, ao longo da escada, no trecho imediatamente acima da barragem e a montante do reservatório, utilizando redes de espera, tarrafas e contagens ou registros visuais durante o período de um ano (Novembro de 2002 a Outubro de 2003). Marcações com linha e missanga e registro de mutilações foram também realizados em concomitância. Peixes, aves, quelônios e cetáceos foram os principais grupos de predadores observados, com predomínio dos dois primeiros. A área nas imediações da entrada da escada, a jusante, foi a região com maior número de grandes predadores, sendo a única de relevância para vertebrados não peixes. Indivíduos marcados permaneceram na escada exercendo a piscivoria por até 90 dias. Rhaphiodon vulpinus, Hydrolycus armatus e Serrasalmus rhombeus foram os principais peixes predadores. Mutilações por ataques de Serrasalmus atingiram 36\% das espécies e alcançaram 4\% dos indivíduos no topo da escada. Os resultados sugerem que a alta densidade de peixes no ambiente restrito da escada, associada às injúrias sofridas no percurso e a presença de múltiplos predadores dotados de estratégias de predação variadas, transforme o corredor para passagem de peixes em um "hotspot" de predação.

Key words: Dam, Fish migration, Fish pass, Piscivores, Serrasalmus.

${ }^{1}$ Universidade Estadual de Maringá, Núcleo de Pesquisas em Limnologia, Ictiologia e Aquicultura - Nupélia. Av. Colombo, 5790, 87020900 Maringá, PR, Brazil. agostinhoaa@gmail.com(AAA)

${ }^{2}$ Universidade Federal do Tocantins, Núcleo de Estudos Ambientais - Neamb, Programa de Pós-Graduação em Ecologia de Ecótonos. Jardim dos Ipês, 77500-000 Porto Nacional, TO, Brazil. 


\section{Introduction}

The interactions between predators and their prey result from a long evolutionary process that has been drastically altered by human activities (Koed et al., 2002), especially since the middle of the last century. Anthropogenic changes to aquatic communities result both from introducing non-native species, especially predators, and from profound environmental changes that create areas of high mortality (Koed et al., 2002). Notably among the latter category are man-made reservoirs, which generally give rise to new ecosystems (Baxter, 1977) with distinct biota, structures, and functions (Agostinho et al., 2008) that have a clear impact on predator-prey relationships (Petersen, 1994; Koed et al., 2002).

Installing a dam interrupts the longitudinal connectivity of rivers, blocks the access between habitats that are critical to the life cycle of aquatic species and fragments populations (Agostinho et al., 2007a). Such interruptions can have striking consequences on the successful recruitment of new individuals in natural populations and have been widely associated with the decline of fish species along rivers in different parts of the world (LoweMcConnell, 1987; Gehrke \& Harris, 2001; Agostinho et al., 2005). The accumulation of fish shoals just below dams is a common phenomenon that is generally attributed to the intersection of upstream movements of reophilic fishes (Agostinho et al., 1993; Agostinho et al., 2007a, Baumgartner, 2007), markedly seasonal (Pompeu \& Martinez, 2006; Agostinho et al., 2007b). Blockading upstream migration and the attraction exerted by local currents can have a remarkable effect on the concentration of rheophilic fish, long distances migrator or not. In addition to its reproductive benefits, the ability of fish species to disperse allows them to escape from predation and to colonise the most suitable habitats (Lucas \& Baras, 2001), especially as the habitats below dams are often poor and strongly dependent on the quality and quantity of the effluent water (Agostinho et al., 2007a). The accumulation of shoals just below a dam and fish frequently jumping against the dam wall lead people to consider it as the most significant impact and that can only be corrected by installing fish passages. This explains the emphasis given to fish migration in environmental impact assessments and during the process of hydropower licensing, marginalising equally harmful effects such as flood regulation, sediment accumulation, nutrient retention, and the reduction of habitats critical to the development of fish larvae (Agostinho et al., 2008).

The high predation pressure in the areas below hydroelectric dams where fish aggregate has been reported by several authors, especially for juvenile salmonids during downstream movements along North American rivers (Ward et al., 1995; Blackwell \& Juanes, 1998; Ryan et al., 2003; Ferguson et al., 2007). There are different groups of relevant predators in these environments, including birds
(Ruggerone, 1986), mammals (Gowans et al., 2003), reptiles and fish (Petersen et al., 1994; Schilt, 2007). Installing facilities such as fish ladders that allow shoals to pass upstream to the reservoir has been considered a positive strategy for reducing the downstream fish density and thus mitigating the mortality from predation (Baumgartner, 2007; Schilt, 2007). However, intensified predation and injuries are expected in and around the ladder, given the high concentration of fish and the limited size of the structure. Thus, intensified predation is an additional problem that should be addressed when constructing fish passages. In this case, passage facilities may become hotspots for predation (McLaughlin et al., in press).

The present study is the first to address the issue of predation along a South American passage system. Data collected from the Lajeado Dam (Usina Hidrelétrica de Lajeado - UHE) fish ladder on the Tocantins River were used to evaluate the following trends: (i) variations in piscivorous fish proportion in relation to other fish in the ladder and its vicinity, including different parts of the reservoir and stretches up- and downstream, (ii) the occurrence and permanence of piscivorous species along the fish ladder as well as their diets in relation to fish collected in other sampling sites, (iii) the incidence of injured fish along the ladder.

\section{Material and Methods}

\section{Study Area}

The data were collected near the Lajeado Dam and its surrounding areas. The dam is located in the middle section of the Tocantins River (middle Tocantins River) $\left(9^{\circ} 45^{\prime} 26^{\prime \prime} \mathrm{S}\right.$ $48^{\circ} 22^{\prime} 17^{\prime} \mathrm{W}$ ). Samples were collected along the fish ladder, and from the area upstream (forebay, transition and upstream from the reservoir) and downstream of the dam (Fig. 1). These samples were supplemented by visual records of the predators observed near the ladder (entrance and exit).

The Lajeado reservoir (officially known as the "UHE Luis Eduardo Magalhães") was closed in 2002. It has an area of $630 \mathrm{~km}^{2}$ and an approximate length of $172 \mathrm{~km}$. The reservoir has a mean depth of $8.8 \mathrm{~m}$, reaching $35 \mathrm{~m}$ near the dam, and has a water turnover time of 24 days.

The fish ladder is an 874-m long, 5-m wide vertical-slot fish passage. The ladder has a $5 \%$ slope and spans a height differential of $36.8 \mathrm{~m}$. The ladder is positioned close to the left bank, bordering the tailrace, and has 92 step-tanks with surface slots $(0.5 \times 1.0 \mathrm{~m})$, bottom slots $(0.8 \times 0.8 \mathrm{~m})$ and five still-water resting tanks (the first tank is $14.4 \times 17.0 \mathrm{~m}$, and all of the other tanks are $10 \times 10 \mathrm{~m}$ ). The discharge during the study period was approximately 3.3 $\mathrm{m}^{3} / \mathrm{s}$, which corresponds to a velocity of $2.3 \mathrm{~m} / \mathrm{s}$ at the bottom slot (see Agostinho et al., 2007c for further details).

\section{Sampling and data analysis}

The piscivorous species were defined as those that had a predominance of fish ( $>50 \%$ by volume) in their diet. This 
definition was based on the analysis of the stomach contents of the fish collected during the present study, other collections from the same basin and information from the published literature (Monteiro et al., 2009).

To investigate the numerical proportion of piscivorous fish in the assemblages, the structure of the ichthyofauna was assessed in the area downstream the dam, near the ladder (entrance and exit) and in different parts of the reservoir (forebay, transition and upstream).

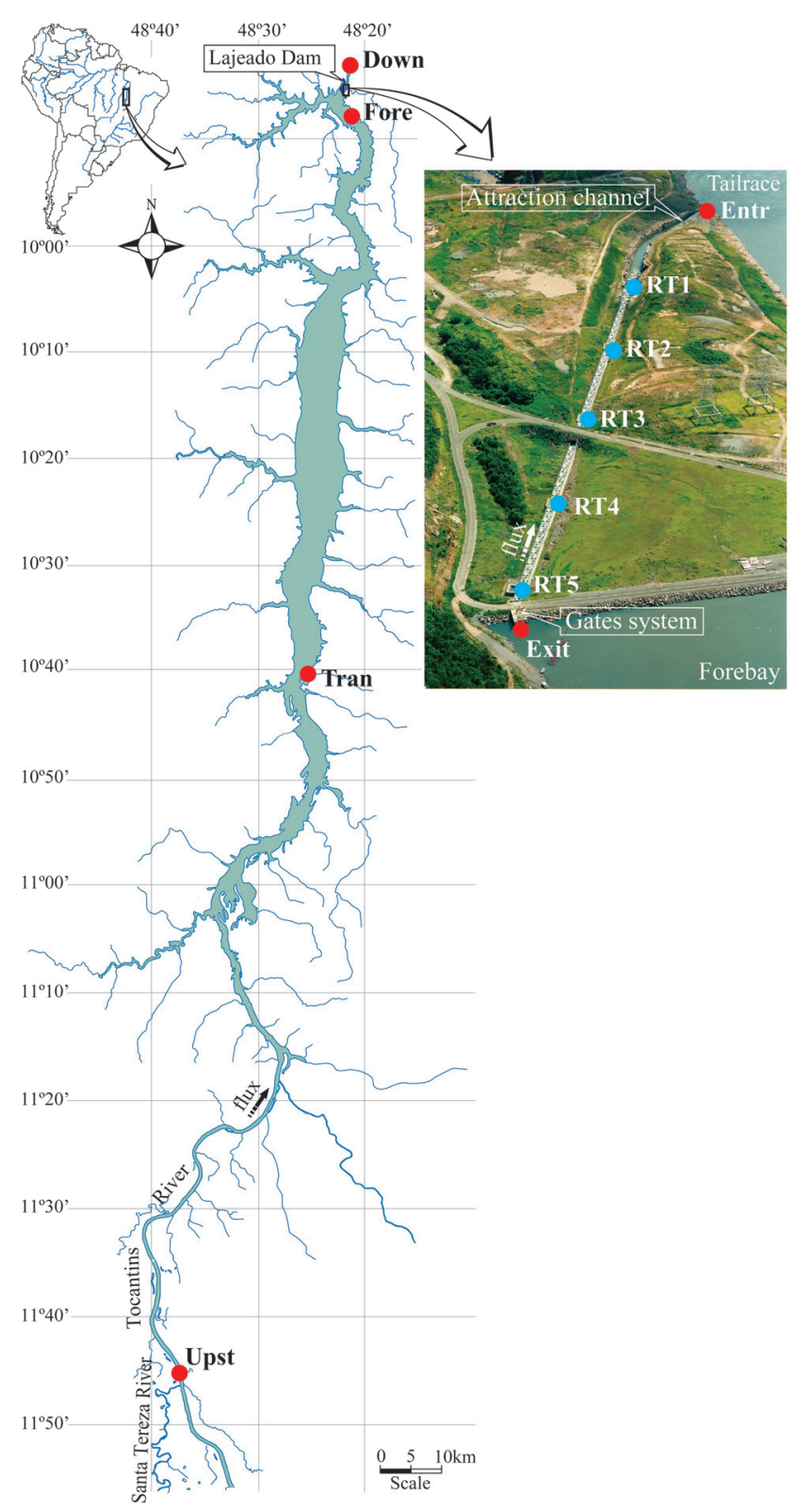

Fig. 1. Map showing the monitoring sites in the Lajeado Reservoir and in the fish ladder (picture in detail). (Reservoir: Down $=$ downstream, Fore $=$ forebay, Tran $=$ reservoir transition, and Upst $=$ upstream; fish ladder: Entr $=$ entrance and exit of the fish ladder; RT = resting tank)
To estimate the contribution of piscivorous fish in the assemblages, we followed two survey methods. In the vicinity of the ladder, counts were conducted in the areas immediately below the first tank (entrance) and above the water intake (exit). These counts were based on visually detecting fish and were always conducted by the same person, who was trained to visually identify and record species. Each observation was performed monthly for approximately $10 \mathrm{~min}$ in the morning between November 2002 and October 2003. The decreased water visibility ( $<$ $40 \mathrm{~cm}$ ) in November and April prevented data collection during these months. In the four other sites considered, gillnets of different mesh sizes ( 3.0 to $16.0 \mathrm{~cm}$ between knots) were installed for 24 hours and were examined every eight hours. These four sites were sampled to capture the longitudinal gradient in the river: downstream of the dam, the forebay area of the reservoir, the transition stretch of the reservoir and the Tocantins River upstream, near the mouth of the Santa Teresa River. To quantify the numerical importance of piscivorous species near the entrance and exit of the ladder and along the longitudinal gradient of the river, the fractions of the total piscivorous recorded in relation to the total number of individuals and species at each site were calculated. To investigate the contribution of the larger species (and therefore more predatory capacity per individual), the proportion of the piscivorous species with a maximum standard length above $40 \mathrm{~cm}$ was also examined.

The use of the ladder by piscivorous fish species was evaluated by the frequency at which those species were identified in this structure during the year. For this purpose, the fish were sampled with cast nets (mesh size of $4.0 \mathrm{~cm}$ and a perimeter of $15 \mathrm{~m}$ ) twice a month during the period from November 2002 to October 2003. The sampling followed a standardised procedure at 12:00, 18:00, 00:00 and 06:00 hours, always starting with the lower tank at 12:00. The fishing effort in each resting tank was constant throughout the year ( 480 cast nets / year / tank $\pm 6 \mathrm{SD}$ ). All of the captured fish were identified, counted and released, except for those captured at 06:00, which were retained for other analysis.

Mark-recapture experiments were used to investigate the permanence of the fish in the ladder. These experiments consisted of marking individuals with cotton thread and beads of different colours. The colour of the line corresponded to a specific resting tank, and the colour of the beads indicated the months of release. The experiments were performed concomitantly with the fish ladder sampling. The limitations of this marking method did not allow assessing the actual movement of individuals between the dates of release and recapture, and the maximum distance travelled by a fish was assumed to be the distance between the capture and recapture locations. However, this procedure did allow inferences about the permanence of the fish in the ladder or its vicinity when recaptures occurred between collections. 
To compare the predation patterns of the piscivorous fish caught on the ladder with the patterns of those caught outside of it, the stomach contents of the fish caught on the ladder were compared with those of fish from the same species sampled in the reservoir. The volumes of the different dietary components present in the stomachs were quantified using a graduated cylinder or through compression of the items on a surface graduated in mm (Ribeiro, 2007).

The incidence of injuries to fish bodies and fins was evaluated in the individuals caught in the ladder. The fish were captured, identified by species, counted, examined for injuries (the presence of bites on the body and fins) and returned to the locations they were captured (except for those captured at 06:00, which were retained for the biometric and diet analyses). Lacerations on the body and fins were interpreted as the results of attacks by the piranha Serrasalmus rhombeus (Linnaeus, 1766), as this was the only species present on the ladder that consumes parts of its prey. The percentage of injured fish was calculated for each tank. To determine the species that suffered the most injuries on the ladder, only those with a total catch of more than 50 individuals were considered. The correlation between the monthly percentage of injured fish and the position of the tank was assessed using the non-parametric Spearman correlation coefficient and a significance level of $5 \%$.

Finally, the presence of other predators (including reptiles, birds, and mammals) in the vicinity of the Lajeado Dam fish ladder was evaluated in a preliminary and qualitative manner. The animals were recorded, photographed, and identified.

\section{Results}

\section{Abundance and distribution of piscivorous fish}

The numeric contribution of the large $(>40 \mathrm{~cm})$ piscivorous species along the Lajeado fish ladder revealed larger abundances around the ladder entrance (Fig. 2a, $35.8 \%$ ). The large-bodied species accounted for the majority $(90 \%)$ of the piscivorous found in that area (Table 1). The contribution of this group diminished markedly (to 17\%) at the ladder exit, where $S$. rhombeus, Cichla sp. A, and Boulengerella cuvieri (Spix \& Agassiz, 1829) were observed more often.

The population of large piscivores progressively declined in the areas upstream of the ladder (Fig. 2). It is noteworthy that the proportion of large piscivores reached $20.6 \%$ in the lotic stretch of the Tocantins River, a value similar to that observed downstream of the dam (22.3\%). The importance of smaller-sized piscivores increased in the areas upstream of the dam, which had greater abundance of Lycengraulis batesii (Günther, 1868), Ageneiosus brevis Steindachner, 1881, Pygocentrus nattereri Kner, 1858 and Acestrorhynchus microlepis (Jardine, 1841) (Table 1).

There was also a marked increase in the number of piscivorous species found along the spatial gradient; they accounted for $40.7 \%$ of the species captured at the ladder entrance (Fig. 2b). Although there was a decline along the ladder, the percentage remained high $(33.3 \%)$ at the exit. By contrast, the piscivorous fish species found upstream at the lotic section of the Tocantins River accounted for $25.4 \%$ of the total species, a similar value to that recorded downstream of the dam (Fig. 2b).

Generally, this study suggested that piscivorous fish constituted a larger fraction (abundance and species richness) around the ladder than in the reservoir and the river. Additionally, the larger and more aggressive species, such as Hydrolycus armatus (Schomburgk, 1841), B. cuvieri, Cichla sp., and S. rhombeus, also represented a greater proportion of the overall fish population around the ladder.

\section{Permanence along the ladder}

The analysis of the samples collected in the ladder resting tanks revealed that $96 \%$ of individuals belonged to three trophic groups: insectivores (43.6\%), piscivores $(34.3 \%)$, and omnivores (17.9\%). Three of the captured
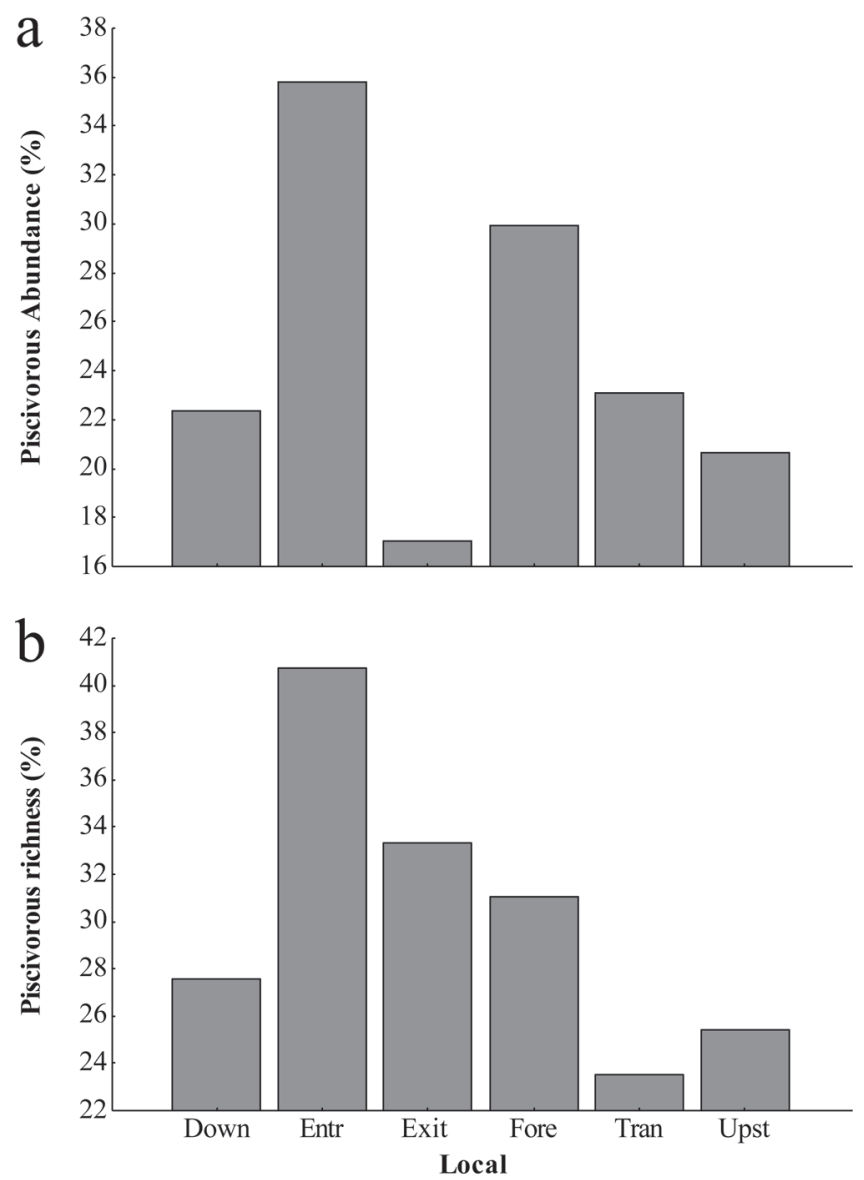

Fig. 2. Abundance (a) and species richness (b) of piscivorous fish in the Lajeado Dam fish ladder (Entr= entrance and exit), and adjacent to the dam $($ Down $=$ downstream, Fore $=$ forebay, Tran $=$ reservoir transition, and Upst $=$ upstream). 
Table 1. Piscivorous species that account for $90 \%$ of the total fish from this trophic group caught along the Lajeado Dam fish ladder (entrance and exit), and in the areas adjacent to the dam (downstream, forebay, transition stretch of the reservoir, and upstream). The total number of piscivorous fish species in the different locations is also shown (S). The bold typeface denotes species with a maximum standard length of less than $40 \mathrm{~cm}$.

\begin{tabular}{|c|c|}
\hline Location & Species (\%) \\
\hline $\begin{array}{l}\text { Downstream } \\
(\mathrm{S}=27)\end{array}$ & $\begin{array}{l}\text { Rhaphiodon vulpinus Spix \& Agassiz, } 1829 \text { (33.9); Pseudotylosurus microps (Günther, 1866) } \\
\text { (13); Agoniates halecinus Müller \& Troschel,1845 (10.7); Serrasalmus rhombeus (9.1); } \\
\text { Hydrolycus armatus (7.8); Zungaro zungaro (Humboldt, 1821) (5.7); Plagioscion } \\
\text { squamosissimus (Heckel, 1840) (4); Boulengerella cuvieri (2.1); Pinirampus pirinampu (Spix \& } \\
\text { Agassiz, 1829) (1.9); Sorubim lima (Bloch \& Schneider, 1801) (1.6) }\end{array}$ \\
\hline $\begin{array}{l}\text { Entrance } \\
(\mathrm{S}=11)\end{array}$ & $\begin{array}{l}\text { Sorubim lima (39.1); H. armatus (22.3); Serrasalmus rhombeus (14.1); P. microps (7.7); B. } \\
\text { cuvierii (6.7) }\end{array}$ \\
\hline $\begin{array}{l}\text { Exit } \\
(\mathrm{S}=7)\end{array}$ & $\begin{array}{l}\text { S. rhombeus (51.9); Cichla sp. A (16.2); B. cuvieri (12.6); Leporinus gr. friderici (Bloch, 1794) } \\
\text { (11.6) }\end{array}$ \\
\hline $\begin{array}{l}\text { Forebay } \\
(\mathrm{S}=27)\end{array}$ & $\begin{array}{l}\text { L. batesii (21.1); } R \text {. vulpinus }(21.1) ; S . \text { rhombeus (19.9); P. squamosissimus (7.2); Ageneiosus } \\
\text { brevis (6.1); Acestrorhynchus microlepis (5.2); H. armatus (4.9); Cichla sp. A (4.3); B. cuvierii } \\
(2.8)\end{array}$ \\
\hline $\begin{array}{l}\text { Res. (transition) } \\
(\mathrm{S}=33)\end{array}$ & $\begin{array}{l}\text { L. batesii (31.5); R. vulpinus (12.9); H. armatus (10.8); S. rhombeus (9); B. cuvierii (5.7); } \\
\text { Agoniates halecinus (4.8); P. pirinampus (3.7); A. brevis (2.9); Cynodon gibbus (Agassiz, 1829) } \\
(\mathbf{1 , 5 )}\end{array}$ \\
\hline $\begin{array}{l}\text { Upstream } \\
(\mathrm{S}=31)\end{array}$ & 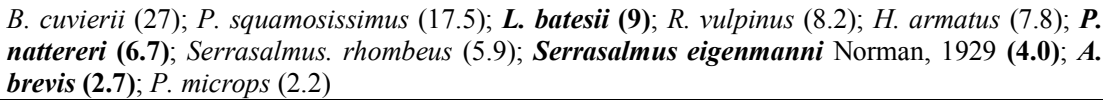 \\
\hline
\end{tabular}

species were of particular relevance: $R$. vulpinus $(29.4 \%$ of the total catch), H. armatus (1.5\%) and S. rhombeus $(0.7 \%)$.

The displacement patterns along the ladder revealed by the mark-recapture locations demonstrated evident transit time differences between the recaptured species. In the studied ladder, we tagged and released 1917 individuals. Out of this total, 29 individuals were recaptured and 10 individuals remained in there for more than 15 days. However, $41 \%$ of the 29 recaptured fish were found on the ladder at different times on the same day, with two thirds of them being found in the lower resting tanks. Among those fish that stayed longer, the transit times ranged from 15 to 90 days, with distances travelled ranging between 139 and $456 \mathrm{~m}$ (Table 2). Among the typical large piscivorous species, only $H$. armatus (with fish on the ladder reaching a standard length greater than $75 \mathrm{~cm}$ ) had individuals that remained for more than 15 days in this environment. However, the typically herbivorous (Myleus cf. torquatus (Kner, 1858)) or omnivorous (Oxydoras niger (Valenciennes, 1821) and Pimelodus blochii Valenciennes, 1840) species in the reservoir significantly increased their fish consumption along the ladder (Table 2). These species were found in at least $75 \%$ of the samples collected in the resting tanks throughout the year. Hydrolycus armatus and O. niger were also captured throughout the year.

\section{Incidence of Injuries}

Of the 10,813 fish captured along the ladder with cast nets, 238 (2\%) exhibited signs of injury caused by predation, including bites to the body and fins. A total of 64 species were found along the ladder, of which 23 exhibited injuries. The species that were most frequently encountered with injuries were $R$. vulpinus (151 individuals), followed by Pseudoplatystoma punctifer (Castelnau, 1855) (23) and H. armatus (12).

The percentage of injured fish in the resting tanks increased from $0.9 \%$ in tank 1 to $4 \%$ in tank 5 (Fig. 3a). There was a significant correlation between the tank position and the percentage of injured fish $\left(\mathrm{N}=60\right.$, Spearman $r_{s}=0.39, t(N-$ $2)=3.21, p=0.0021$ ), but this pattern was strongly influenced by the capture and injuries faced by $R$. vulpinus (Fig. 3a). The abundance of this species was uniformly high along the tanks (except for the last tank, where many individuals accumulated) (Fig. 3b). Percentage of injured fish increased along the tanks, with an accumulation of mutilated fish in the last tank. The piranha $S$. rhombeus was present in all of the tanks (Fig. 3c). This species was also one of the most abundant species captured at the ladder entrance and exit (Table 1).

Among the species with a total capture of $>50$ individuals, the most frequently injured species were P. punctifer $(18.5 \%$ of the captured individuals), H. armatus (7.2\%) and $R$. vulpinus (4.8\%) (Table 3); up to $33 \%$ of P. punctifer individuals in the first tank and $14 \%$ of $H$. armatus individuals in the last tank had injuries. However, the majority of species exhibited relatively low ( $<2 \%$ of captures) injury frequencies.

\section{Other predators}

Although quantitative data on the composition and abundance of other vertebrate predators were not obtained, 
Table 2. Capture and mark-recapture data for the Lajeado Dam fish ladder, showing the species with longer release-recapture times, including the time, distance between tanks and proportion of fish in the diets of individuals from the ladder (LAD) and reservoir (RES). Oc = number of months occurrence in the ladder between November 2002 to October 2003, (n) = number of stomachs analysed, Arrows indicate displacements and direction.

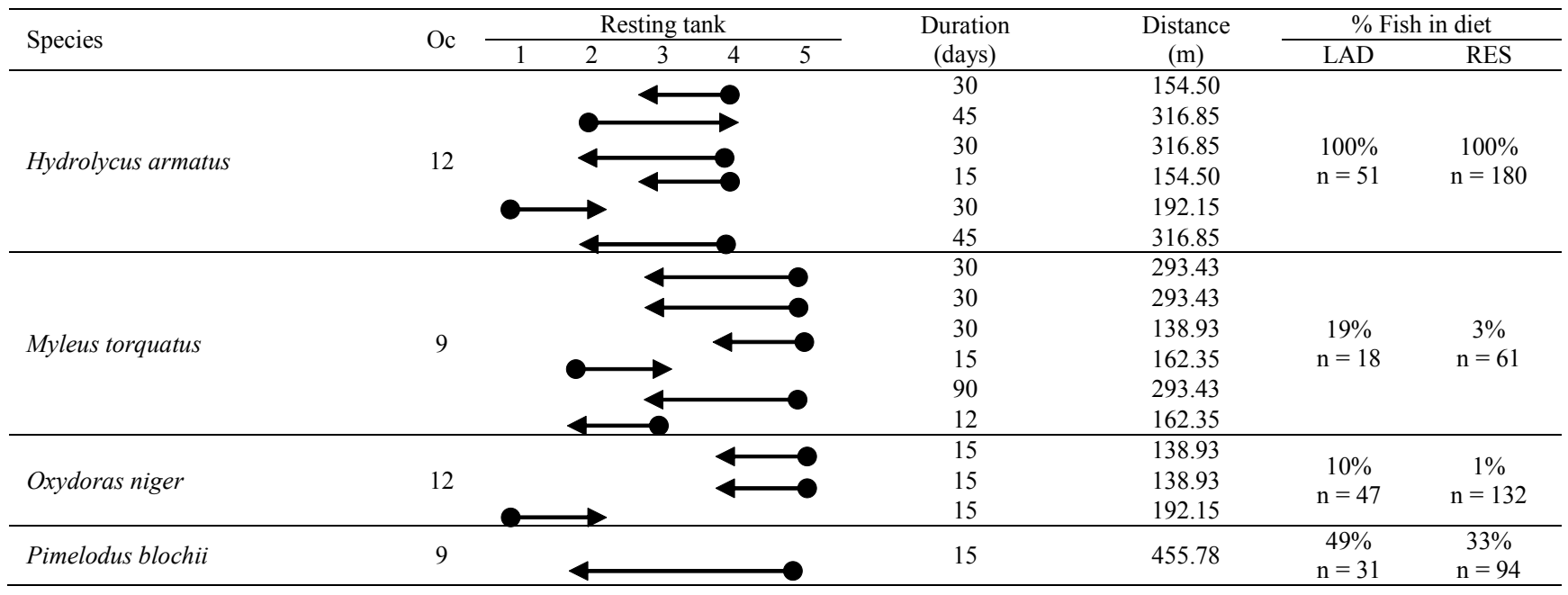

a number of species were recorded around the Lajeado ladder: the cetaceous Amazon river dolphin Inia geoffrensis (Blainville, 1817); and birds, such as cocoi herons Ardea cocoi Linnaeus, 1766, the great egret Ardea alba Linnaeus, 1758 and the Neotropical cormorant Phalacrocorax brasilianus (Gmelin, 1789). These predators were observed near the ladder entrance (Fig. 4). Reptiles, such as the South American river turtle Podocnemis expansa Schweigger, 1812 and the yellowspotted river turtle Podocnemis unifilis (Troschel, 1848) were also observed, but the importance of fish in their diets is unknown.

\section{Discussion}

The results of this study demonstrate that the dam structures that aid fish ascension to the upstream reservoir (i.e., fish ladders) have the potential to intensify predation on the passing fish. In fact, ascending the fish ladder resulted in the exposure of shoals to a variety of predators, including representatives of all vertebrate classes other than amphibians. The fish were especially vulnerable to predators as a result of being confined in a narrow water channel, potentially turning an otherwise safe passage into an ecological trap. Therefore, building fish passages with the secondary purpose of reducing the accumulation of fish and predation pressure in the sections immediately below dams can produce the opposite effect (by enhancing piscivory). Fish passages, in this case, may become a hotspot for predation (McLaughlin et al., in press).

Although the fish density is generally high in the first few kilometres downstream of dams (Pompeu \& Martinez, 2006; Agostinho et al., 2007c; Pelicice et al., 2009), the proportion of piscivores above Lajeado Dam was similar to sections locate far upstream. By contrast, high proportions of piscivorous fish were found in reservoir areas, confirming the patterns previously reported (Petersen, 1994; Koed et al., 2002; Agostinho et al., 2007a). Studies conducted after the formation of Peixe Angical Reservoir found a six-fold increase in the abundance of piscivorous fish relative to the previous period (Monteiro et al., 2009). The large population of piscivorous fish above the dam suggested a higher predation pressure than in the downstream areas, especially as some larger-bodied species were also more abundant upstream ( $R$. vulpinus and $S$. rhombeus). Thus, despite the low abundance of piscivorous fish at the ladder exit, ascending fish are likely to encounter many predators in the reservoir. We highlight, however, that ascending fish encounter a vast area for dispersion upon entering the reservoir, which (along with the increased participation of smaller predators) may attenuate the effects of strong piscivory.

Our results suggest that there is intense predation along and close to the fish ladder. Large populations of piscivorous species were recorded near the ladder entrance, a confined environment of limited dimensions compared to the river channel. It is noteworthy that $90 \%$ of the predatory fish recorded in this area were large species (standard length $>40$ $\mathrm{cm}$ ) that can consume entire prey and thus generate high predation pressure on the ascending shoals. To attract and guide the fish to the ladder, fish ladders are designed so that the flow of water at the entrance is competitive with the local river currents (Clay, 1995), which increases the fish density compared to adjacent areas. In the case of the Lajeado fish ladder, this shoal concentration occurs in an environment with large predator populations, possibly exposing the ascending fish to increased risk of mortality. 
The high prey density along the Lajeado fish ladder and the expected state of exhaustion from overcoming the flow was one of the possibilities suggested by Agostinho et al. (2007c) to explain the abundance and permanence along the ladder of some migratory and large piscivorous
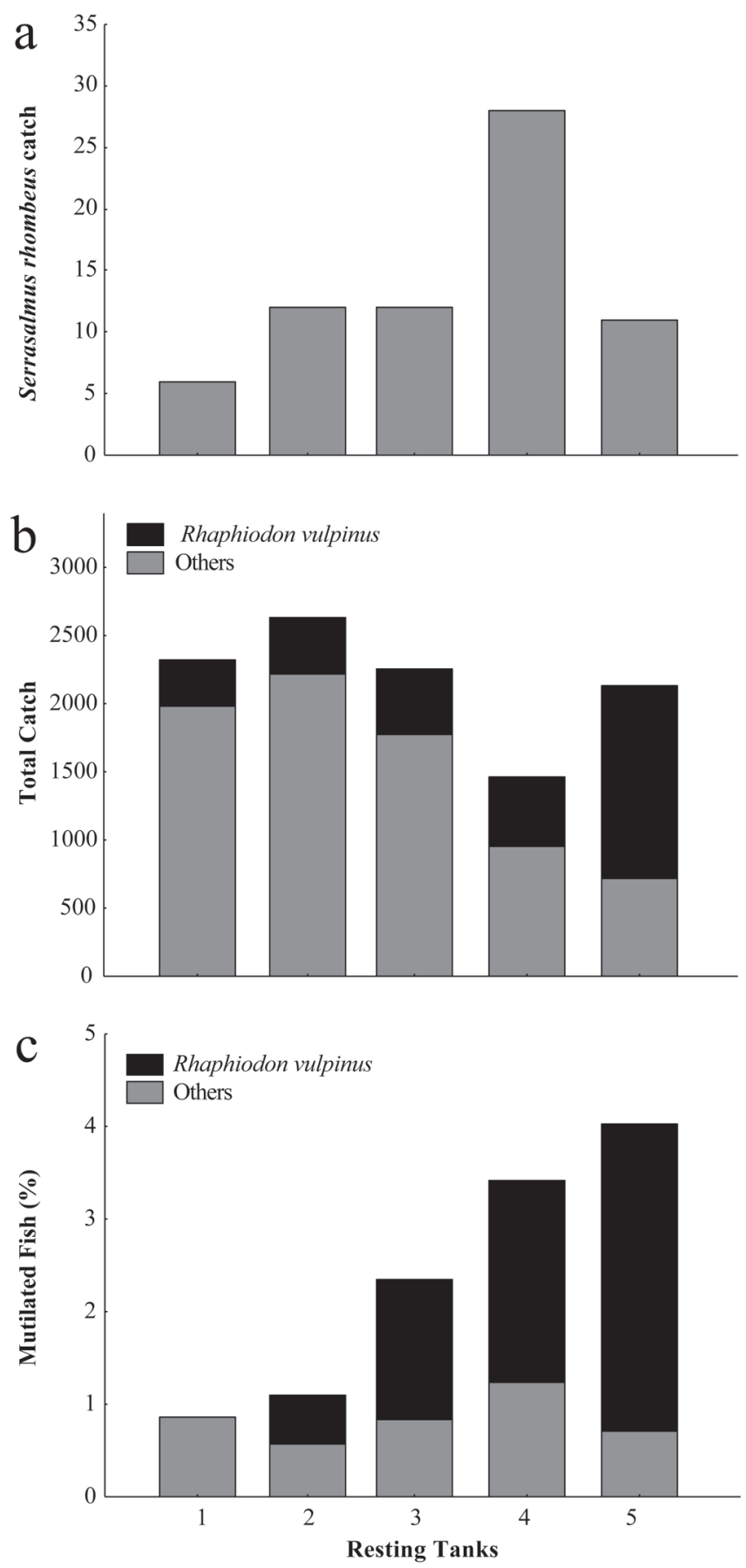

Fig. 3. Number of piranhas Serrasalmus rhombeus (a), total number of captured fish (b), and percentage of mutilated fish (c) in the resting tanks of the Lajeado Dam fish ladder. Rhaphiodon vulpinus is highlighted once this species had the greatest number of individuals injured.
Table 3. Fish species with the greatest frequencies of injuries (bites) in the resting tanks along the Lajeado fish ladder ( $>1 \%$ of individuals injured). The table shows the total number of individuals caught $(\mathrm{N})$, the average percentage of injured fish along the ladder (\%), and the percentage of injured fish in each resting tank (Resting Tanks in order from down to upstream).

\begin{tabular}{lccccccc}
\hline \multirow{2}{*}{ Species } & \multirow{2}{*}{$\mathrm{N}$} & \multirow{2}{*}{$\%$} & \multicolumn{5}{c}{ Resting Tanks } \\
\cline { 5 - 9 } & & & 1 & 2 & 3 & 4 & 5 \\
\hline Pseudoplatystoma punctifer & 124 & 18.5 & 33.3 & 0.0 & 14.3 & 26.3 & 9.5 \\
Hydrolycus armatus & 166 & 7.2 & 12.9 & 7.4 & 3.1 & 2.1 & 13.8 \\
Rhaphiodon vulpinus & 3153 & 4.8 & 0.0 & 3.4 & 7.0 & 6.3 & 5.0 \\
Myleus torquatus & 146 & 2.1 & 0.0 & 12.5 & 2.4 & 1.5 & 0.0 \\
Myleus setiger & 164 & 1.8 & 0.0 & 0.0 & 11.1 & 0.0 & 3.2 \\
Prochilodus nigricans & 261 & 1.9 & 0.0 & 0.0 & 1.2 & 5.7 & 1.7 \\
Plagioscion squamosissimus & 67 & 1.5 & 0.0 & 0.0 & 4.2 & 0.0 & 0.0 \\
Serrasalmus rhombeus & 69 & 1.4 & 0.0 & 8.3 & 0.0 & 0.0 & 0.0 \\
Triportheus trifurcatus & 373 & 1.3 & 0.0 & 1.0 & 0.0 & 3.1 & 9.1 \\
\hline
\end{tabular}

fish species ( $R$. vulpinus, $P$. fasciatum, and $H$. armatus) and even some non-migratory species $(S$. rhombeus and Plagioscion squamosissimus) throughout the year. The results of the present study demonstrate that at least some species (particularly $R$. vulpinus) can settle and remain in the ladder resting tanks for extended periods while predating and being predated upon. Even herbivorous ( $M$. torquatus) and omnivorous (O. niger) fish (Monteiro et $a l ., 2009)$ that have no pre-adaptations to a piscivorous diet may consume fish along the ladder, which demonstrates the vulnerability of fish to predation in this environment. The fish-eating species that remain in the ladder encounter a constant supply of resources as fish ascend the ladder throughout the year (Agostinho et al., 2007b). It is also possible that the prolonged presence of large predators at the ladder entrance and in the five resting tanks constitutes a barrier to fish passage that reduces the translocation efficiency. Agostinho et al. (2007b) have suggested this possibility as an explanation for the higher concentration of $R$. vulpinus in the final resting tank.

Mutilation should also be considered as a significant factor contributing to increased mortality in the ascending fish. In Lajeado, $36 \%$ of the captured fish species were attacked along the ladder, with the mutilation frequency increasing towards the top of the ladder. These injuries were likely caused by Serrasalmus, as this is the only genus among those captured that is able to tear pieces of flesh off of their prey (Agostinho et al., 1997; Pompeu, 1999; Abelha et al., 2001). Injuries and mutilations alter the behaviour and swimming performance of prey (Sazima \& Machado, 1990), leaving them more susceptible to attack by other predators or to subsequent mortality.

Another important finding was that in addition to the large populations of piscivorous fish found in the vicinity of the ladder, other piscivorous vertebrates, such as birds and mammals, were frequently observed in the area. Turtles were also observed, but the importance of fish in its omnivorous diet is unknown - although fishermen usually 


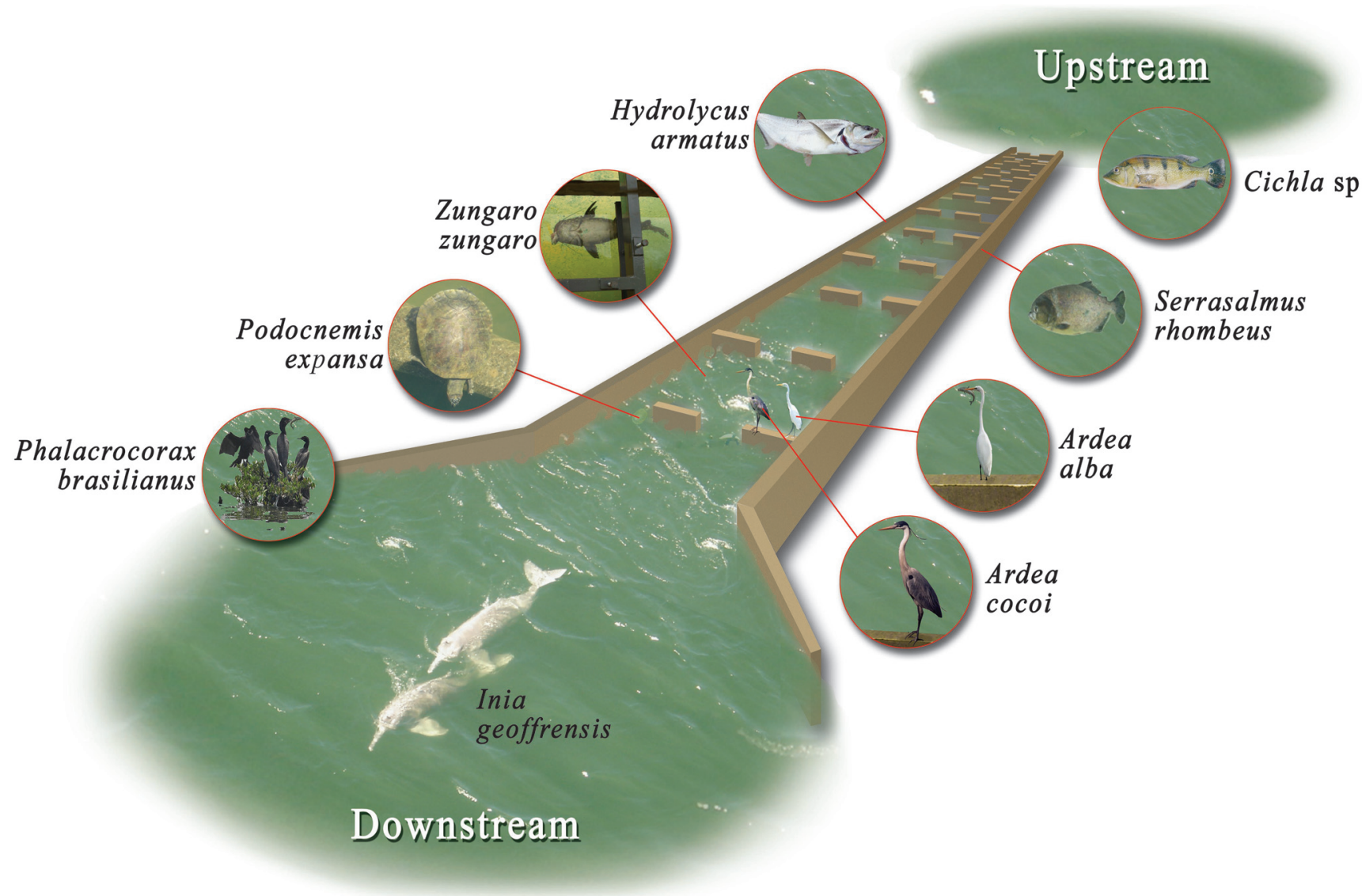

Fig. 4. Dominant predator species along the fish ladder at the Lajeado Dam, Tocantins River.

catch turtles using fish baits. Additive and/or emergent effects are expected in such situations (Griffen, 2006; Steinmetz et al., 2008), especially given the apparent concentration of different predator groups with diverse predation strategies and behaviours. In the case of additive effects, the risk of fish being consumed increases with complementary predatory activity, as the fish are exposed to different types of predators (e.g., opportunistic, ambushing, and chasing predators). In addition, emergent impacts are unpredictable and arise from interactions among different predatory strategies. In such cases, joint predatory activity can increase catches through facilitation between predators. For example, predators that pursue prey, such as dolphins and piranhas, can increase the exposure of prey species to waiting and opportunistic predators, such as some cichlids and large catfish. The clustering of different types of predators in the vicinity of the ladder should therefore be an important factor that determines the piscivory levels in these locations. The synergistic impacts caused by multiple predators have been suggested as dispersal barriers to the small North American cyprinid (Rhinichthys osculus) (Harvey et al., 2004), demonstrating the relevance of this phenomenon to preventing efficient fish passages. As the present study involved only qualitative records of other predators, there is an urgent need for further research that quantifies predator diversity and predation dynamics (including additive and emergent effects).

The probable restrictions and mortality caused by the predators along the fish ladder resembled those described for certain terrestrial corridors linking forest fragments (Gilliam \& Fraser, 2001; Weldon, 2006). Like terrestrial biodiversity corridors, fish ladders are conservation strategies that aim to ensure free movement of individuals between fragmented habitats, thus ensuring demographic phenomena and gene flow between the fragments (Weldon, 2006). As is the case for narrow and poorly-maintained corridors, however, the threat of predators in fish ladders cannot be ignored. When travelling to upstream habitats, fish are exposed to a wide range of predators near the ladder (river dolphins, birds, and probably turtles) or in the tanks (large piscivorous fish) - areas that should provide safe passage. The prey species encounter new predators at the end of the ladder, when they are likely to be exhausted by the effort expended during their ascension and often 
mutilated by piranha bites. The restricted space of the fish ladder corridors, coupled with the multiple predators and varied predation strategies encountered along the ladders, suggests that these ladders, can act more as predation hotspot than as biodiversity corridors.

\section{Acknowledgments}

We thanks our colleagues of the Núcleo de Estudos Ambientais (Neamb), Universidade Federal de Tocantins (UFT), for their assistance in the field and laboratory work; Investco S.A. for financial support, and Jaime Luiz Lopes Pereira for drawing the figures. AAA received a $\mathrm{CNPq}$ (Conselho Nacional de Desenvolvimento Científico e Tecnológico) personal grant.

\section{Literature Cited}

Abelha, M. C. F., A. A. Agostinho \& E. Goulart. 2001. Plasticidade trófica em peixes de água doce. Acta Scientiarum, 23: 425-434.

Agostinho, A. A., V. P. Mendes, H. I. Suzuki \& C. Canzi. 1993. Avaliação da atividade reprodutiva da comunidade de peixes dos primeiros quilômetros a jusante do Reservatório de Itaipu. Revista UNIMAR, 15: 175-189.

Agostinho, C. S., A. A. Agostinho, E. E. Marques \& L. M. Bini. 1997. Abiotic factors influencing piranha attacks on netted fish in the upper Paraná River, Brazil. North American Journal of Fisheries Management, 17: 712-718

Agostinho, A. A., S. M. Thomaz \& L. C. Gomes. 2005 Conservation of the Biodiversity of Brazil's Inland Waters. Conservation Biology, 19: 646-652.

Agostinho, A. A., L. C. Gomes \& F. M. Pelicice. 2007a. Ecologia e Manejo dos Recursos Pesqueiros em Reservatórios do Brasil. Maringá. EDUEM, 501p.

Agostinho, C. S., C. R. Pereira, R. J. Oliveira, I. S. Freitas \& E. E. Marques. 2007b. Movements through a fish ladder: temporal patterns and motivations to move upstream. Neotropical Ichthyology, 5: 161-167.

Agostinho, C. S., A. A. Agostinho, F. M. Pelicice, D. A. Almeida \& E. E. Marques. 2007c. Selectivity of fish ladders: a bottleneck in Neotropical fish movement. Neotropical Ichthyology, 5: 205-213.

Agostinho A. A., F. M. Pelicice \& L. C. Gomes. 2008. Dams and the fish fauna of the Neotropical region: impacts and management related to diversity and fisheries. Brazilian Journal of Biology, 68: 1119-1132.

Baumgartner L. J. 2007. Diet and feeding habits of predatory shes upstream and downstream of a low-level weir. Journal of Fish Biology, 70: 879-894.

Baxter R. M. 1977. Environmental effects of dams and impoundments. Annual Review of Ecology and Systematics, 8: 255-283.

Blackwell, B. F. \& F. Juanes. 1998. Predation on Atlantic salmon smolts by striped bass after dam passage. North American Journal of Fisheries Management, 18: 936-939.

Clay, C. H. 1995. Design of fishways and other facilities. Boca Raton. Lewis Publishers, 248p.

Ferguson, J. W., B. P. Sandford, R. E. Reagan, L. G. Gilbreath, E. B. Meyer, R. D. Ledgerwood \& N. S. Adams. 2007. Transaction of the American Fisheries Society, 136: 1487-1510.
Gehrke, P. C \& J. H. Harris. 2001. Regional-scale effects of flow regulation on lowland riverine fish communities in New South Wales, Australia. Regulated Rivers: Research and Management, 17: 369-391.

Gilliam, J. F. \& D. F. Fraser. 2001. Movement in corridors: enhancement by predation threat, disturbance, and habitat structure. Ecology, 82: 258-273.

Gowans, A. R. D., J. D. Armstrong, I. G. Priede \& S. Mckelvey. 2003. Movements of Atlantic salmon migrating upstream through a fish-pass complex in Scotland. Ecology of Freshwater Fish, 12: 177-189.

Griffen, B. D. 2006. Detecting emergent effects of multiple predator species. Oecologia, 148: 702-709.

Harvey, B. C., J. L. White \& R. J. Nakamoto. 2004. An emergent multiple predator effect may enhance biotic resistance in a stream sh assemblage. Ecology, 85: 127-133

Koed A., N. Jepsen, K. Aarestrup \& C. Nielsen. 2002. Initial mortality of radio-tagged Atlantic salmon (Salmo salar L.) smolts following release downstream of a hydropower station. Hydrobiologia, 483: 31-37

Lowe-McConnell, R. H. 1987. Ecological Studies in Tropical Fish Communities. Cambridge University Press, Cambridge, England, $382 \mathrm{p}$.

Lucas M. C. \& E. Baras. 2001. Migration of freshwater fish. Osney Mead, Blackwell Science, 420p.

McLaughlin, R. L., E. R. B. Smyth, T. Castro-Santos, M. L. Jones, M. A. Koops, T. C. Pratt \& L. A. Vélez-Espino. (in press). Unintended consequences and trade-offs of fish passage. Fish and Fisheries.

Monteiro, A. S., A. H. M. Oliveira \& F. M. Pelicice. 2009. Alterações espaciais na estrutura trófica da ictiofauna: sucessos e insucessos na colonização do reservatório. Pp. 87-94. In: Agostinho, C. S., F. M. Pelicice, E. E. Marques (Eds.). Reservatório de Peixe Angical: bases ecológicas para o manejo da ictiofauna. São Carlos, Rima, 179p.

Pelicice, F. M., A. Akama, R. J. Oliveira \& D. S. Silva. 2009. Padrões espaciais e temporais na distribuição da ictiofauna, antes e após a formação do reservatório de Peixe Angical. Pp. 29-39. In: Agostinho, C. S., F. M. Pelicice \& E. E. Marques (Eds.). Reservatório de Peixe Angical: bases ecológicas para o manejo da ictiofauna. São Carlos, Rima, 179p.

Petersen J. H., D. M. Gadomski \& T. P. Poe. 1994. Differential Predation by Northern Squawfish (Ptychocheilus oregonensis) on Live and Dead Juvenile Salmonids in the Bonneville Dam Tailrace (Columbia River). Canadian Journal of Fisheries and Aquatic Sciences, 51: 1197-1204

Petersen, J. H. 1994. Importance of spatial pattern in estimating predation on juvenile salmonids in the Colombia River. Transaction of the American Fisheries Society, 123: 924-930.

Pompeu, P. S. \& C. B. Martinez. 2006. Temporal patterns of fish passage in Santa Clara Power Plant's fish lift, Murici River, East Brazil. Revista Brasileira de Zoologia, 23: 340-349.

Pompeu, P. S. 1999. Dieta da pirambeba Serrasalmus brandtii Reinhardt (Teleostei, Characidae) em quatro lagoas marginais do rio São Francisco, Brasil. Revista Brasileira de Zoologia, 16:19-26.

Ribeiro, N. P. 2007. Alimentação de peixes capturados na escada para peixes da UHE Lajeado e a montante da barragem. Unpublished Monograph, Universidade Federal do Tocantins, Tocantins, 25p.

Ruggerone, G. T. 1986. Consumption of migrating juvenile salmonids by gulls foraging below a Columbia River Dam. Transaction of the American Fisheries Society, 115: 736-742. 
Ryan, B. A., S. G. Smith, J. M. Butzerin \& J. W. Ferguson. 2003. Relative vulnerability to avian predation of juvenile salmonids tagged with passive integrated transponders in the Columbia River estuary, 1998-2000. Transactions of the American Fisheries Society, 132: 275-288.

Sazima, I. \& F. A. Machado. 1990. Underwater observations of piranhas in western Brazil. Environmental Biology of Fishes, 28: $17-31$.

Schilt, C. R. 2007. Developing fish passage and protection at hydropower dams. Applied Animal Behaviour Science, 104: 295-325.

Steinmetz, J., D. A. Soluk \& S. L. Kohler. 2008. Facilitation between herons and smallmouth bass foraging on common prey. Environmental Biology of Fishes, 81: 51-61.

Ward, D. L., J. H. Petersen \& J. J. Loch. 1995. Index of predation on juvenile salmonids by Northern Squawfish in the lower and middle Columbia River and in the lower Snake River. Transactions of the American Fisheries Society, 124: 321-334.

Weldon, A. J. 2006. How Corridors Reduce Indigo Bunting Nest Success. Conservation Biology, 20: 1300-1305.

Submitted March 30, 2012

Accepted October 15, 2012 